\title{
Subjektivně vnímaná zdatnost učitelů v kontextu jejich profesního vzdělávání: zjištění a výzvy z šetření TALIS 2013
}

\author{
Vendula Kašparová, Eva Potužníková, Tomáš Janík
}

Masarykova univerzita, Pedagogická fakulta, Institut výzkumu školního vzdělávání

Redakci zasláno 19. 2. 2015 / upravená verze obdržena 24. 5. 2015 /

k uveřejnění přijato 25. 5. 2015

\begin{abstract}
Abstrakt: Článek prezentuje a diskutuje vybrané výsledky Mezinárodního šetření o vyučování a učení TALIS 2013 (Teaching and Learning International Survey). Nejprve představuje důvody vzniku a vývoj šetření TALIS a stručně pojednává o teoretických východiscích se zaměřením na problematiku profesního vzdělávání a subjektivně vnímané zdatnosti učitelů. Ve výsledkové části prezentuje zjištění TALIS 2013 týkající se subjektivně vnímané zdatnosti a interpretuje je v kontextu zjištění týkajících se profesního vzdělávání a podmínek práce učitelů ve školách. Výsledky ukazují, že učitelé v ČR vnímají svoji zdatnost jako nižší než učitelé v jiných zemích. Navzdory tomu se méně než v mezinárodním průměru vzdělávají v oblastech, v nichž se cítí nejméně zdatní a zároveň $v$ těchto oblastech ani necítí vyšší potřebu se vzdělávat. V souladu $\mathrm{s}$ mezinárodním průměrem hodnotí velká většina učitelů $\mathrm{v}$ ČR dopady profesního vzdělávání pozitivně, a to napříč tematickými oblastmi, a je se svým výkonem ve škole spokojena. Oproti mezinárodnímu průměru se učitelé v ČR více zapojují do různých forem vzájemné podpory a spolupráce ve školách. Nadprůměrný podíl jich však vyjádřil pocit, že je učitelské povolání nevýhodné a ve společnosti nevážené. Ve světle šetření TALIS se jeví jako vhodné využít potenciál příznivého školního klimatu k užšímu propojení mezi hodnocením práce učitelů a jejich dalším profesním rozvojem a k cílenějšímu zaměření profesního rozvoje učitelů na aktivity, které by mohly posílit jejich (subjektivně vnímanou) zdatnost.
\end{abstract}

Klíčová slova: mezinárodně srovnávací výzkumy, profesní vzdělávání učitelů, spokojenost učitelů, subjektivně vnímaná zdatnost učitelů, TALIS 2013

V roce 2013 se uskutečnila již druhá vlna Mezinárodního šetření o vyučování a učení TALIS (Teaching and Learning International Survey). Toto šetření je součástí programu Organizace pro hospodářskou spolupráci a rozvoj nazvaného Indikátory vzdělávacích systémů (Indicators of Education Systems INES), jehož cílem je tvorba celistvé sady ukazatelů mapujících různé aspekty 
školství v zemích OECD a umožňujících různá porovnání. Ta jsou zveřejňovaná např. v každoročně vydávané publikaci OECD s názvem Education at a glance (např. OECD, 2014d).

Hlavním cílem šetření TALIS je rozšírit spektrum mezinárodně sbíraných informací o učitelích, vyučování a učení a o dopadu práce učitelů na žáky, které by byly dostupné pro země OECD a partnerské země či hospodářské celky. Výstupy by měly zemím zároveň pomoci revidovat a vytvářet vzdělávací strategie a tím prosazovat žádoucí podmínky pro efektivní vyučování a učení. Šetření navazuje na studii Teachers matter: Attracting, developing and retaining effective teachers (OECD, 2005), která napomohla formulovat politicky relevantní výzkumné otázky pro toto šetření.

$V$ roce 2008 proběhl sběr dat pro první vlnu šetření, tj. TALIS 2008, které se Česká republika neúčastnila. Výsledky šetření byly pozitivně přijaty a Komise pro vzdělávací politiku při OECD rozhodla o realizaci jeho druhé vlny, kterou je šetření TALIS 2013. Od první vlny šetření TALIS 2008 došlo ke zvýšení počtu zúčastněných zemí z 24 na 34. Další vlna šetření proběhne opět s pětiletým odstupem $v$ roce 2018. TALIS je realizován dotazníkovou formou, data jsou sbírána prostřednictvím dotazníků pro učitele a pro ředitele škol.

TALIS je prvním mezinárodním výzkumem, který se primárně zaměřuje na zjištování pracovních podmínek učitelů. Snaží se poskytnout komplexní pohled na podmínky, ve kterých učitelé pracují, při zachování únosné délky dotazníků. Z tohoto důvodu nezachází př́liš do hloubky jednotlivých šetřených témat, zato však nabízí v základních parametrech ucelené srovnání podmínek učitelů v různých zemích.

\section{Příprava a realizace šetření TALIS 2013}

Ve snaze o přiblížení tematického zaměření šetření TALIS 2013 potřebám zemí OECD byly členské země na jaře 2010 přizvány $\mathrm{k}$ účasti $\mathrm{v}$ hodnocení priorit, at' se již dřive šetření TALIS účastnily, či nikoliv. Výsledné řazení od tématu s nejvyšším bodovým hodnocením po téma s nejnižším bodovým hodnocením ukazuje tabulka 1. 
Tabulka 1

Výsledky hodnocení priorit pro šetření TALIS 2013

\begin{tabular}{lc}
\hline Téma & Bodové hodnocení \\
\hline Vedení školy & 393 \\
Vyučovací postupy a přesvědčení učitelů & 374 \\
Profily dalšího profesního vzdělávání učitelů & 318 \\
Školní klima a étos & 312 \\
Přípravné vzdělávání učitelů & 307 \\
Spokojenost s dalším profesním vzděláváním a jeho efektivita & 295 \\
Uznání, odměňování a hodnocení učitelů & 294 \\
Profesní činnosti vykonávané učiteli & 287 \\
Motivace a zkušenosti učitelů na počátku jejich profesní dráhy & 264 \\
Získávání dobrých studentů pro povolání učitele & 259 \\
Dovednosti pro 21. století: ICT ve výuce & 249 \\
Spokojenost učitelů v zaměstnání a opatření na podporu učitelů & \\
(teacher human resource measures) & 237 \\
Vzdělání a kvalifikace učitelů & 229 \\
Frekvence účasti v dalším profesním vzdělávání & 216 \\
Inovace a kreativita & 209 \\
Rozvržení pracovního času učitelů & 209 \\
Odchody učitelů z profese a míra fluktuace & 164 \\
Přiměřenost doplňování populace učitelů a jejich nedostatek & 151 \\
Podpora a poradenství pro nejzkušenější učitele & 142 \\
Efektivita procesů a pobídek používaných při náboru a výběru učitelů & 86 \\
\hline
\end{tabular}

Pozn. Převzato z OECD (2013, s. 12, upraveno autory této studie).

Na podkladě tohoto hodnocení byly vypracovány dotazníky, které byly ověřeny $\mathrm{v}$ pilotním šetření ve vybraných zemích a dále $\mathrm{v}$ předběžném šetření, do něhož bylo zapojeno všech 34 zemí. Konečná verze dotazníků obsahuje následující témata a indikátory: vedení a řízení školy, zaškolování a další profesní vzdělávání učitelů, přípravné (počáteční) vzdělávání učitelů, hodnocení učitelů a poskytování zpětné vazby, školní klima a étos, přesvědčení učitelů o správném způsobu výuky, učiteli uplatňované postupy při výuce, subjektivně vnímaná (profesní) zdatnost učitelů a spokojenost učitelů v zaměstnání.

Vzorek dotazovaných učitelů byl vybírán dvoustupňově. Nejprve byly náhodně vybrány školy a následně byli v každé škole pomocí speciálního programu 
náhodně vybráni učitelé. Ve všech zemích se šetření účastnili učitelé na úrovni vzdělávání ISCED 2, v ČR se jednalo o 2. stupeň základních škol a nižší ročníky víceletých gymnázií. Země měly možnost rozšiřit šetření o úroveň ISCED 1 a ISCED 3, čehož některé využily, ČR však nikoliv. Až na Spojené státy americké splnily všechny země podmínky návratnosti odpovědí pro plné zařazení výsledků do mezinárodního srovnávání. V ČR proběhl sběr dat od 4. března do 5. května 2013 a zúčastnilo se jej 3219 učitelů působících na 2. stupni základních škol či v nižších ročnících víceletých gymnázií (tj. $98 \%$ z celkového počtu učitelů, kteří byli pro účast vybráni a splňovali definici zkoumané populace) a 220 ředitelů pracujících ve školách, kde tito učitelé vyučují (tj. plný počet ředitelů za školy zúčastněné v šetření). Více informací o průběhu sběru dat a návratnosti lze získat ze Zprávy o kvalitě provedení šetření TALIS 2013 (Kašparová, 2013) a z mezinárodní technické zprávy (OECD, 2014a).

První výstupy byly zveřejněny v červnu 2014, kdy vyšla první mezinárodní zpráva z šetření TALIS $2013 \mathrm{~s}$ výsledky za vzdělávání na úrovni ISCED 2 (OECD, 2014b) a současně v ČR Národní zpráva šetření TALIS 2013 (Kašparová et al., 2014a). Zveřejněny byly též dotazníky, datové matice a další koncepční a technické materiály. V prosinci pak byla publikována další mezinárodní zpráva týkající se vzdělávání na úrovních ISCED 1 a 3 (OECD, 2014c) a v lednu 2015 byla v ČR zveřejněna Analytická zpráva z šetření TALIS (Kašparová et al., 2014b), která blíže rozebírá vybrané výstupy z Národní zprávy šetření TALIS 2013.

V roce 2015 (v červenci a listopadu) je plánováno zveřejnění dalších tematických zpráv z šetření TALIS 2013 na mezinárodní úrovni (jedna se zaměří na vedení a ř́zení školy, druhá na učitelství jako profesi). $V$ těchto tematických zprávách bude navíc možné využít data sebraná na Novém Zélandě, v Ruské federaci, Thajsku, Gruzii a Šanghaji. Výsledky za tyto země nebyly prozatím do analýz na mezinárodní úrovni zahrnuty, nebot' realizovaly sběr dat pro šetření TALIS 2013 nezávisle, avšak stejnou metodou a při splnění všech stanovených podmínek.

Všechny výzkumné zprávy, data, dotazníky a další dokumenty vytvořené v ČR je možné volně stáhnout ze stránek České školní inspekce, ${ }^{1}$ výstupy na mezinárodní úrovni jsou zveřejňovány na stránkách OECD. ${ }^{2}$

1 Dotazníky jsou ke stažení spolu s daty ve složce TALIS2013_učitelé na stránce www.csicr.cz/ Prave-menu/Mezinarodni-setreni/TALIS/Datove-soubory-z-setreni-TALIS-2013.

2 www.oecd.org/talis 
Po zveřejnění hlavních výsledků šetření TALIS se nyní otevírá možnost diskutovat na rủzných fórech o tom, jak lze tyto výsledky propojit s poznatky získanými z jiných výzkumů, př́ípadně jak je zohlednit při rozhodování na různých úrovních. Tento text je jedním z příspěvků do této diskuse.

Na omezeném rozsahu časopisecké studie není možné popsat všechny výsledky, které šetření TALIS 2013 přineslo. Z celého spektra zkoumaných témat jsme proto vybrali problematiku subjektivně vnímané zdatnosti učitelů a jejich spokojenosti v zaměstnání, kterou uvádíme do vztahu s dalším vzděláváním a profesním rozvojem učitelů a s vybranými charakteristikami školního prostředí, resp. školního klimatu. Naším cílem je interpretovat již dříve zveřejněné výsledky šetření TALIS 2013 v nových souvislostech a na základě toho se pokusit porozumět relativně nižší subjektivně vnímané zdatnosti učitelů v ČR. V návaznosti na naši analýzu rovněž naznačíme určitá opatření, která se na základě výsledků šetření jeví jako podporující učitele v žádoucích ohledech. Pro tento účel považujeme za vhodné nejprve představit teoretická východiska šetření TALIS 2013 relevantní předkládanému textu a začlenit je do širšího kontextu poznatků z pedagogických výzkumů realizovaných v České republice.

\section{Vybraná teoretická a empirická východiska}

Jak je uvedeno v koncepčním rámci šetření (OECD, 2013), TALIS vychází z modelu vyvinutého původně Mezinárodní asociací pro hodnocení výsledků vzdělávání (IEA), který na vzdělávací systém nahlíží jako na systém vstupů, procesů a výstupů. ${ }^{3}$ Na základě dat sebraných v šetření TALIS jsou pak konstruovány indikátory, které vypovídají o výstupech vzdělávacích systémů na úrovni učitelů, $\mathrm{k}$ nimž je $\mathrm{v}$ šetření TALIS řazena spokojenost učitelů v zaměstnání a jejich subjektivně vnímaná zdatnost. Kromě výstupů jsou v šetření TALIS sledovány i další prvky modelu. Za jeden z nejdůležitějších vstupů na úrovni učitelů je považováno jejich vzdělávání. Jeho dopad lze pozorovat ve dvou rovinách: absolvované vzdělání může mít vliv na: (a) používané výukové postupy; (b) subjektivně vnímanou zdatnost učitelů a jejich spokojenost v zaměstnání. Koncepční rámec s odkazem např. na studii Gareta et al. (2001) uvádí, že největší dopad na výuku ve třídách mají takové formy dalšího profesního vzdělávání, které zahrnují prvky aktivního učení (např. př́ímé

\footnotetext{
Používá se rozšířená, dvourozměrná verze tohoto modelu, která v jednom rozměru pracuje se vstupy, procesy a výstupy a v druhém rozměru rozlišuje žáky, učitele, školy a země jako různé úrovně aktérů působících v oblasti formálního vzdělávání (srov. k tomu např. modely kvality ve vzdělávání in Janík et al., 2013, s. 45-49).
} 
pozorování a praktické procvičování vyučovacích metod) a spolupráci s jinými učiteli, které probíhají po delší časové období a které jsou diferencovány podle individuálních potřeb jednotlivých učitelů (u nás $\mathrm{k}$ tomu podrobněji viz Starý et al., 2012, s. 56-63). Pokud mají učitelé možnost vzdělávat se v tom, co vnímají jako potřebné, cítí se zároveň zdatnější a spokojenější (OECD, 2013, s. 24-26).

Na vzdělávání učitelů je v šetření TALIS nazíráno jako na prostředek, který mohou jednotliví učitelé i vedení škol využívat pro zlepšování výuky a potažmo i výsledkủ žáků. TALIS v tomto smyslu hovoří o tzv. pedagogickém stylu vedení školy (instructional leadership), v jehož rámci ředitel vykonává činnosti zaměřené na podporu učení u žáků. ${ }^{4}$ Podstatnou charakteristikou úspěšných škol je provázanost mezi hodnocením učitelů, poskytováním zpětné vazby a stanovením adekvátního plánu dalšího profesního rozvoje. Vedle podpory zavádění žádoucích vyučovacích postupů může vést konstruktivní hodnocení učitelů, propojené s nabízením vhodných příležitostí k dalšímu profesnímu rozvoji, k prohloubení spolupráce v pedagogickém sboru a vyšší spokojenosti učitelů v zaměstnání (OECD, 2013). Podobný př́ístup u nás prosazují Starý et al. (2012).

V širším kontextu motivovanosti učitelů jsme si za ústřední téma tohoto textu zvolili problém subjektivně vnímané zdatnosti učitelů a jejich spokojenosti v zaměstnání. $V$ tomto ohledu je třeba předeslat, že učitelská profese je (nejen) u nás charakteristická řadou specifik (tabulkové zařazení platu, malá možnost kariérního postupu atd.), díky nimž není v praxi př́liš reálné aplikovat běžná funkční manažerská opatření ke zvyšování motivace (srov. Křeménková \& Novotný, 2010). Šetření TALIS 2008 v souladu s tím ukázalo, že dopady hodnocení na odměňování učitelů jsou napříč různými zeměmi spíše malé (OECD, 2013, s. 32). Samotná výše platového ohodnocení učitelů navíc není v ČR př́liš motivující. Plat učitelů působících na úrovni ISCED 2 ve veřejných školách činil v roce $2012 \mathrm{v}$ ČR pouze $54 \%$ průměrného platu vysokoškolsky vzdělaného člověka ve věku 25-64 let pracujícího na plný úvazek po celý rok, což je mezi zeměmi OECD jeden z nejnižších podílů. ${ }^{5}$ Nižší

Termín pedagogický styl vedení školy - jak je užíván v šetření TALIS - lze považovat za obsahově blízký termínům řízení kvality výuky (McKinsey \& Company, 2010; event. Janík et al., 2013, s. 180-183) a pedagogické ř́zení (např. Dvořák, Starý, \& Urbánek, 2015).

5 Plat učitelů byl v jednotlivých zemích dle dostupnosti dat počítán bud' jako průměrný reálný plat učitele ve věku 25-64 let (včetně různých příplatků a odměn - to je i případ ČR), nebo zákonný plat učitelů $\mathrm{s}$ 15letou praxí $\mathrm{v}$ oboru a $\mathrm{s}$ minimálním požadovaným vzděláním (např. na Slovensku). Více viz metodické poznámky v tabulce D 3.2 (OECD, 2014d). 
byl pouze na Slovensku (43\%), průměr na jednu zemi ze sledovaných zemí OECD byl 88 \% (OECD 2014d, graf D 3.1). Navíc byla ČR v roce 2012 zemí s druhým nejmenším rozdílem mezi platy začínajících učitelů a nejzkušenějších učitelů působících na úrovni ISCED 2 , a to jak v absolutním vyjádření, tak i ve vyjádření procentuálním - začínající učitelé s minimálním požadovaným vzděláním dosahovali v ČR čtyř pětin platu nejzkušenějších a nejvzdělanějších učitelů, na Slovensku to byly tři pětiny, průměr za země OECD činil 57 \% (OECD 2014d, graf D 3.2).

V souladu s výše prezentovanými informacemi uváděli v ČR učitelé i studenti dotazovaní v šetření provedeném agenturou Factum Invenio (2009) pro MŠMT ČR jako hlavní příčinu, proč se mladí lidé nechtějí stát učiteli, špatné finanční ohodnocení. Za hlavní důvody k úvahám o ukončení tohoto povolání byly považovány následující atributy: fyzická a psychická náročnost povolání a žáci, kteří nemají zájem o školní práci. Na další místa se pak zařadily: špatné finanční ohodnocení a nemožnost finančně zohlednit dobře či špatně odvedenou práci.

V šetření TALIS 2013 nebyla sledována spokojenost učitelů s finančním ohodnocením své práce, byly však zjišt’ovány jiné aspekty spokojenosti v zaměstnání včetně názorů učitelů na společenskou prestiž jejich povolání. Nízká prestiž povolání učitele byla v šetření společnosti Factum Invenio (2009) identifikována jako jeden $\mathrm{z}$ faktorů, které z pohledu studentů pedagogických i nepedagogických oborů vysokých škol snižují atraktivitu učitelské profese. V šetřeních Centra pro výzkum veřejného mínění (Sociologický ústav AV ČR, 2013) však povolání učitele na základní škole patří dlouhodobě mezi pět nejprestižnějších. ${ }^{7}$

Vrátíme-li se k šetření Factum Invenio (2009), pak nejdůležitějším faktorem při rozhodování o vstupu i setrvání v učitelské profesi je zájem o práci s dětmi, mladé prostředí, možnost uplatnit svou tvořivost. Jedná se tedy spíše o seberealizaci a vnitřní motivaci než motivaci vnější, co učitele k jejich profesi přitahuje. Zároveň se však (jak bylo výše uvedeno) v očích mnohých učitelů jedná o náročné povolání, nebot’ vyžaduje dovednost motivovat i žáky, kteř́i sami nejeví o výuku zájem. Pocitovaný neúspěch při vypořádávání se s touto výzvou pak může vést až k odchodu učitelů z profese.

\footnotetext{
V přepočtení na USD a se zohledněním parity kupní síly.

7 Více viz http://cvvm.soc.cas.cz/media/com_form2content/documents/c1/a7054/f3/ eu130903.pdf
} 
V šetření TALIS 2013 nebyli učitelé př́imo tázáni na svou vnitřní motivovanost, nicméně sadou otázek se zjištovala jejich subjektivně vnímaná zdatnost, která s vnitřní motivací a odhodláním překonávat obtížné situace úzce souvisí. Koncept subjektivně vnímané zdatnosti (self-efficacy) odkazuje k představě jedince o své schopnosti činit efektivní kroky k dosažení určitého cíle (srov. Bandura, 1986, 1995 a další). Bandura (1995) rozlišuje mezi čtyřmi hlavními činiteli, kterými je vnímaná vlastní zdatnost utvářena. Prvním jsou vlastní zkušenosti s úspěchem (člověk si na základě nich vytváří představu sám o sobě), druhým jsou zprostředkované zkušenosti (ztotožnění se s podobnými lidmi, jako je člověk sám, kteří něco dokázali či naopak ve svém snažení selhali), třetím podpora od okolí (je-li člověk druhými vnímán jako schopný, má tendenci se více snažit) a čtvrtým je psychologické a emoční nastavení člověka (napřs stres a napětí může být vnímáno jako omezující a vedoucí ke slabšímu výkonu, nebo naopak mobilizující větší snahu a bojovnost v závislosti na míře sebedůvěry a naopak pochyb o sobě; obecně pozitivní nálada a rozpoložení přispívá k lepšímu sebevnímání) (Bandura, 1995, s. 3-5).

Také u nás se konceptu subjektivně vnímané zdatnosti věnuje řada autorů - mezi psychology např. Balaštíková, Blatný a Kohoutek (2004), Horáková Hoskovcová (2006), Janoušek (2000), Poledňová (2006), Urbánek a Čermák (1996, 1997); v pedagogickém kontextu např. Gavora (2009), Majerčíková a Gavora (2013), Mareš (2013), Rozkovcová (2014), Wiegerová et al. (2012). Gavora v souladu s Bandurou uvádí, že anglický výraz self-efficacy označuje to, ,jak člověk subjektivně hodnotí svoje potenciality vykonávat určitou činnost", a s odkazem na Pajarese (1996) a Milsona (2003) podává následující výklad:

Vnímaná profesní zdatnost je motivační potenciál učitele a podmiňuje to, kolik vnitřní energie je schopný naakumulovat a věnovat svojí práci, jak je vytrvalý při řešení výchovných situací, jakou houževnatost vyvine, aby se mu dařilo. Předpokládá se, že čím učitel považuje svoji profesní zdatnost za silnější, tím víc úsilí, vytrvalosti a houževnatosti vyvine. Učitelé s vnímanou silnou profesní zdatností dokáží vyvinout víc úsilí, protože vnitřní motivační síla je podporuje. Učitelé s vnímanou slabou profesní zdatností naopak rychle vyčerpají svou energii a úsilí, když před sebou vidí překážky. Navíc svou činnost často spojují s nepř́ijemnými pocity, stresem apod. (Gavora, 2009, s. 19-20)

Koncepční rámec šetření TALIS předpokládá, že jak subjektivně vnímaná zdatnost, tak i spokojenost v zaměstnání souvisejí s pracovním výkonem učitele. Subjektivně vnímaná zdatnost může rovněž nepř́ímo poukazovat na to, 
co učitelé žáky naučí (OECD, 2013, s. 37). Řada studií prokázala pozitivní souvislost mezi subjektivně vnímanou vlastní zdatností učitelů a lepšími výsledky i lepší motivovaností žáků a učiteli používanými výukovými postupy, zaujetím pro výuku, zodpovědným prrístupem, jejich spokojeností v zaměstnání a celkovým prrístupem k výuce (přehled viz OECD, 2014b, s. 182).

Co se týče vlastní výuky žáků, Gavora a Majerčíková (2012) např. odkazují na výzkumy subjektivně vnímané zdatnosti na různých stupních škol shrnuté v řadě prací $k$ dané problematice a uvádějí, že učitel s vysokou úrovní subjektivně vnímané zdatnosti se vyznačuje následujícími charakteristikami:

Častěji volí náročnější výukové postupy než učitel, který je přesvědčen o své slabé profesní zdatnosti; lépe odolává tlakủm prostředí; má tendenci dávat žákủm více problémových úloh než úloh, v kterých žáci uplatní pouze reprodukci vědomostí; věnuje více času tomu, aby dovedl žáka ke správným odpovědím na otázky; používá častěji skupinovou práci než učitelé s nízkou mírou profesní znalosti; obyčejně se více věnuje slabším žákům než jeho kolegové s nízkou mírou profesní zdatnosti. (Gavora \& Majerčíková, 2012, s. 207-208)

Šetření TALIS umožňuje doplnit výsledky domácích výzkumů subjektivně vnímané zdatnosti o komparaci s jinými zeměmi. V tomto článku ukážeme, jak se učitelé v České republice odlišují od mezinárodního průměru a vybraných zemí, dále budeme sledovat různé souvislosti a hledat odpověd' na otázku, jakým způsobem je možné subjektivně vnímanou vlastní zdatnost učitelů podpořit.

\section{Data a nástroje}

Subjektivně vnímaná zdatnost učitelů byla v učitelském dotazníku šetření TALIS 2013 zjištována pomocí tří baterií po čtyřech položkách. ${ }^{8} \mathrm{Z}$ odpovědí učitelů na tyto položky byl vytvořen index celkové subjektivně vnímané zdatnosti a tři dílčí indexy zdatnosti v oblasti řízení třídy žáků, $v$ oblasti vyučovacích postupů a v oblasti motivování žáků a jejich zapojování do výuky. Učitelé byli rovněž osmi položkami dotazováni, jak jsou spokojeni v zaměstnání ${ }^{9}$ -

Viz dotazník pro učitele, otázka 34. Dotazník je možné stáhnout spolu s daty pod odkazem ve složce TALIS2013_učitelé zde: http://www.csicr.cz/Prave-menu/Mezinarodni-setreni/ TALIS/Datove-soubory-z-setreni-TALIS-2013

9 Viz dotazník pro učitele, otázka 46. Dotazník je možné stáhnout spolu s daty pod odkazem ve složce TALIS2013_učitelé zde: http://www.csicr.cz/Prave-menu/Mezinarodni-setreni/ TALIS/Datove-soubory-z-setreni-TALIS-2013 
$\mathrm{v}$ tomto případě byl vytvořen index celkové spokojenosti a dva dílčí indexy (index spokojenosti s pracovním prostředním a s povoláním učitele). Kromě toho učitelé v dotazníku uváděli, zda jsou spokojeni se svým výkonem v dané škole a zda si myslí, že si společnost povolání učitele váží. Tyto dvě položky nebyly použity ke konstrukci indexů a byly vyhodnocovány samostatně.

Všechny indexy používané $\mathrm{v}$ šetření TALIS byly zkonstruovány tak, aby hodnota 10 odpovídala střední hodnotě na škále odpovědí použité v dotazníku a směrodatná odchylka byla 2 . Vyšší hodnoty indexů znamenají větší subjektivně vnímanou zdatnost, resp. spokojenost.

Protože vycházíme z mezinárodního šetření, budeme zjištění za ČR porovnávat s výsledky v mezinárodním průměru (tj. průměr na jednu zemi účastnící se šetření TALIS 2013), příp. s dalšími vybranými zeměmi. První dvojici vybraných zemí tvoří naši sousedé, Slovensko a Polsko, které jsou nám z účastníků šetření TALIS 2013 kulturně nejbližší. Dále jsme zvolili Finsko a Estonsko, jejichž vzdělávací systémy se vyznačují př́íznivými výstupy na úrovni žáků (měřeno šetřením PISA), konkrétně výbornými průměrnými výsledky a malými rozdíly mezi dobrými a slabými žáky. Doplňme, že i Polsko je zemí s nadprůměrně dobrými výsledky, která doznala v průběhu posledních cyklů šetření PISA prudkého zlepšení výsledkủ žáků. Naopak na Slovensku se výsledky žáků postupně zhoršují a zároveň se zvětšuje rozdíl mezi dobrými a slabými žáky (viz Palečková et al., 2013).

\section{$4 \quad$ Zjištění}

\subsection{Subjektivně vnímaná zdatnost a spokojenost učitelů v $\check{C} R-$ shrnutí hlavních zjištění}

Učitelé v ČR dosáhli celkově i ve všech dílčích oblastech subjektivně vnímané zdatnosti podprůměrných hodnot. Nižší celkovou subjektivně vnímanou zdatnost uvedlo již jen Japonsko. Naopak např. na sousedním Slovensku vykázali učitelé nadprůměrnou subjektivně vnímanou zdatnost, a to ve všech třech oblastech. Relativně nejvíce zdatní se učitelé v ČR cítí v oblasti řízení tř́́dy žáků a relativně nejméně v oblasti motivování žáků a jejich zapojování do výuky. Zde dosáhli nejen výrazně nižší hodnoty než v ostatních oblastech, ale také největšího rozdílu oproti mezinárodnímu průměru (viz tabulka 2). 


\section{Tabulka 2}

Průměrné hodnoty indexů subjektivně vnímané zdatnosti a spokojenosti učitelů

\begin{tabular}{|c|c|c|}
\hline & Průměr ČR & Průměr TALIS \\
\hline Celková subjektivně vnímaná zdatnost & 10,76 & 12,46 \\
\hline Subjektivně vnímaná zdatnost v řízení třídy žáků & 11,72 & 12,79 \\
\hline Subjektivně vnímaná zdatnost v používání vyučovacích postupů & 11,05 & 12,58 \\
\hline $\begin{array}{l}\text { Subjektivně vnímaná zdatnost v motivování a zapojování žáků } \\
\text { do výuky }\end{array}$ & 9,52 & 12,00 \\
\hline
\end{tabular}

Pozn. Převzato z TALIS 2013.

Do subjektivně vnímané zdatnosti v oblasti motivování žáků a jejich zapojování do výuky byly zařazeny následující položky, $\mathrm{k}$ nimž učitelé uváděli, do jaké míry je zvládají (řazeno od nejkritičtěji hodnocené položky po relativně nejméně kriticky hodnocenou): (1) motivovat žáky, kteří nemají zájem o školní práci; (2) pomoci žákům uvědomit si, jakou má učení hodnotu; (3) pomáhat žákưm myslet kriticky; (4) přesvědčit žáky, že mohou mít dobré výsledky.

Oproti mezinárodnímu průměru se učitelé $v$ ČR cítí být podstatně méně zdatní rovněž ve využívání alternativních metod výuky, což je položka zařazená do indexu subjektivně vnímané zdatnosti v oblasti používání vyučovacích postupů. V ostatních položkách zařazených do tohoto indexu ${ }^{10}$ zaznamenali učitelé v ČR také nižší subjektivně vnímanou zdatnost než v mezinárodním průměru, rozdíly však již nejsou tak velké (Kašparová et al., 2014a, s. 60). Procentuální rozložení odpovědí učitelů v ČR a v mezinárodním průměru na těchto pět položek, v nichž se projevily největší rozdíly, uvádí tabulka 3.

Učitelé v ČR vykázali také v mezinárodním srovnání podprůměrnou spokojenost v zaměstnání, přestože číselné hodnoty standardizovaných indexů jsou již mezinárodnímu průměru blíže než u subjektivně vnímané zdatnosti. 0 něco spokojenější jsou přitom dle své výpovědi s pracovním prostředím než s povoláním učitele.

10 V rámci subjektivně vnímané zdatnosti v oblasti vyučovacích postupů bylo dále zjištováno, do jaké míry si učitelé myslí, že (1) zvládají připravovat žákům podnětné otázky; (2) poskytují alternativní vysvětlení, např. jsou-li žáci zmateni; (3) využívají různé postupy hodnocení výsledků. 
Tabulka 3

Do jaké míry učitelé zvládají činnosti zařazené do oblasti motivování žáků a jejich zapojování do výuky a využivat alternativní vyučovací metody (v \%)

\begin{tabular}{llccccc}
\hline & & $\begin{array}{c}\text { vůbec } \\
\text { ne }\end{array}$ & $\begin{array}{c}\text { do určité } \\
\text { míry }\end{array}$ & $\begin{array}{c}\text { do značné } \\
\text { míry }\end{array}$ & $\begin{array}{c}\text { do velké } \\
\text { míry }\end{array}$ & celkem \\
\hline $\begin{array}{l}\text { Motivovat žáky, kteří } \\
\text { nemají zájem o školní } \\
\text { práci }\end{array}$ & ČR & 4 & 66 & 24 & 6 & 100 \\
\hline $\begin{array}{l}\text { Pomoci žákům uvědomit } \\
\text { si, jakou má učení }\end{array}$ & ČR & 1 & 29 & 45 & 25 & 100 \\
hodnotu & průměr TALIS & 1 & 60 & 32 & 7 & 100 \\
\hline $\begin{array}{l}\text { Pomáhat žákům myslet } \\
\text { kriticky }\end{array}$ & 0 & 19 & 46 & 34 & 99 \\
\hline $\begin{array}{l}\text { Čresvědčit žáky, že } \\
\text { mohou mít dobré }\end{array}$ & průměr TALIS & 1 & 19 & 49 & 31 & 100 \\
\hline výsledky & CrR & 0 & 50 & 40 & 10 & 100 \\
\hline $\begin{array}{l}\text { Využívat ve tř́dě } \\
\text { alternativní vyučovací TALIS }\end{array}$ & 0 & 14 & 48 & 38 & 100 \\
metody & ČR & 1 & 46 & 38 & 14 & 99 \\
\hline
\end{tabular}

Pozn. Převzato z TALIS 2013.

Česká republika měla ze všech zemí nejnižší podíl učitelů, kteří uvedli, že by rádi přešli na jinou školu, kdyby to bylo možné (10 \%). Dále $95 \%$ učitelů v ČR souhlasilo nebo rozhodně souhlasilo s tím, že je se svým výkonem ve škole spokojeno, což je srovnatelné s 93 \% takových učitelů v mezinárodním průměru. Na druhou stranu byl v ČR zaznamenán nejnižší podíl učitelů, kteří rozhodně souhlasili či souhlasili s tím, že výhody učitelského povolání jednoznačně převažují nad jeho nevýhodami (53\%). Na Slovensku tento podíl činí 58 \%; naopak ve Finsku je tohoto názoru 95 \% učitelů a v Polsku 76 \%. Mezinárodní průměr je pak 77 \% souhlasných odpovědí. S těmito výsledky koresponduje i podprůměrný podíl učitelů v ČR, kteří se domnívají, že společnost si povolání učitele váží (12 \% oproti $31 \%$ v mezinárodním průměru). Výrazně vyšší podíl učitelů sdílí tento názor ve Finsku (59\%), ale i v Polsku je takových učitelů více než v ČR (18 \%). Naopak na Slovensku s tímto výrokem souhlasila jen $4 \%$ učitelů.

Výše uvedené výsledky naznačují, že učitelé v ČR se na své povolání i na své schopnosti zvládnout určité situace při výuce dívají relativně kriticky, přestože celkově jsou se svým výkonem ve škole spokojeni. Jedním z možných 
důvodů tohoto nesouladu může být to, že učitelé k motivování žáků a zařazování alternativních metod do výuky nemusejí být dostatečně podněcováni (např. vedením školy) nebo jim k tomu nemusejí být poskytnuty vhodné podmínky. Také je možné, že sami učitelé spatřují svoji hlavní úlohu při výuce $v$ jiných aspektech (např̀ v tom, aby udrželi pořádek ve třídě a stihli probrat všechno učivo) a motivování a aktivní zapojování žáků do výuky či využívání alternativních vyučovacích metod nepokládají za stěžejní část své práce, podle které by měli usuzovat na svůj celkový výkon. $V$ takovém př́padě by relativně nižší subjektivně vnímaná zdatnost učitelů v těchto oblastech učitelům nebránila vykonávat práci tak, aby se svým výkonem byli spokojeni.

Jak vyplývá z teoretických východisek uvedených výše, koncept subjektivně vnímané zdatnosti nesleduje, do jaké míry jsou učitelé schopni zkoumané činnosti skutečně zvládat ve vlastní pedagogické praxi, ale jedná se spíše o vnitřní sebepojetí jedince, které má potenciál motivovat ho k podávání dobrých výkonů. Dále je třeba mít na paměti, že výpovědi respondentů v dotazníkovém šetření, zvláště jedná-li se o natolik subjektivní otázky, ovlivňuje také kulturní prostředí té které země, možná sociální desirabilita apod. Spíše než pouze konstatovat rozdíl České republiky od mezinárodního průměru je proto cennější pohlížet na získané výsledky v souvislostech a interpretovat je pomocí dalších vysledovaných vztahů. Pro účely tohoto článku jsme si položili tyto otázky: (1) Jak souvisí subjektivně vnímaná zdatnost učitelů s jejich dalším profesním vzděláváním? (2) Jak souvisí subjektivně vnímaná zdatnost učitelů s podmínkami školního prostředí? Pozornost zaměříme především na vnímanou zdatnost v oblasti motivování žáků a jejich zapojování do výuky a ve využívání alternativních vyučovacích metod, kde je sebehodnocení učitelů v ČR relativně nejnižší.

\subsection{Subjektivně vnímaná zdatnost a další profesní vzdělávání učitelů $v$ ČR}

\section{Vzdělávací potřeby učitelů}

V předchozí části jsme uvedli, že šetření TALIS 2013 poukázalo na nízkou subjektivně vnímanou zdatnost učitelů v oblasti motivování a zapojování žáků do výuky a z položek patřících do oblasti vyučovacích postupů ve využívání alternativních metod výuky. Ve světle tohoto zjištění by bylo možné předpokládat, že učitelé $v$ ČR budou vyjadřovat potřebu se $v$ těchto oblastech dále vzdělávat, aby získali potřebné dovednosti. Výsledky tomu však příliš nenasvědčují, protože hlavními oblastmi, ve kterých by se učitelé rádi vzdělávali, jsou: ICT dovednosti; chování žáků a vedení třídy; nové technologie 
na pracovišti. Velkou potřebu dalšího vzdělávání v těchto oblastech deklarovalo $10-15 \%$ učitelů.

Potřeba dalšího vzdělávání zaměřeného výslovně na problematiku motivování a zapojování žáků a využívání alternativních metod výuky v šetření TALIS zjišt'ována nebyla. Ze sledovaných oblastí dalšího vzdělávání11 uvádíme $\mathrm{v}$ tabulce 4 celkem čtyři oblasti, které by podle našeho názoru měly $\mathrm{k}$ této problematice nejblíže. Je vidět, že jen minimum učitelů v ČR vyjádřilo velkou potřebu vzdělávání v těchto oblastech a že v mezinárodním průměru jsou tyto podíly o poznání vyšší. Podprůměrnou potřebu dalšího vzdělávání vyjádřili ostatně učitelé v ČR ve všech zjišt'ovaných oblastech s výjimkou již zmíněného chování žáků a vedení třídy a prohloubení faktických znalostí a vědomostí ve vyučovaných předmětech.

Tabulka 4

Podíl učitelů, kteří vyjádřili velkou potřebu dalšího profesního vzdělávání ve vybraných oblastech ( $\mathrm{v} \%)$

\begin{tabular}{lcc}
\hline & ČR & Průměr TALIS \\
\hline Pedagogické kompetence pro výuku mých předmětů & 6 & 10 \\
Přístupy k individualizovanému učení & 6 & 13 \\
Postupy hodnocení výsledků vzdělávání a úspěšnosti žáků & 5 & 12 \\
Výuka žáků se speciálními vzdělávacími potřebami & 8 & 22 \\
\hline
\end{tabular}

Pozn. Převzato z TALIS 2013.

Subjektivně vnímaná zdatnost učitelů s ohledem na jejich účast v dalším profesním vzdělávání dle obsahu, na který se zaměruje

Pokud jde o obsah dalšího profesního vzdělávání, dle šetření TALIS 2013 se učitelé $\mathrm{v}$ ČR účastnili $\mathrm{v}$ relativně nejvyšší míře vzdělávání zaměřeného na prohlubování faktických znalostí a vědomostí ve vyučovaných předmětech, na dovednosti v oblasti ICT pro výuku, na pedagogické kompetence pro výuku předmětů a na nové technologie na pracovišti. Pátou oblastí v pořadí bylo chování žáků a vedení třídy. Navštěvované aktivity dalšího vzdělávání se tedy svým obsahem zhruba shodují se vzdělávacími potřebami a učitelé nejvíce navštěvují právě ty aktivity dalšího vzdělávání, které se jim jeví jako

11 Viz dotazník pro učitele, otázka 26. Dotazník je možné stáhnout spolu s daty pod odkazem ve složce TALIS2013_učitelé zde: http://www.csicr.cz/Prave-menu/Mezinarodni-setreni/ TALIS/Datove-soubory-z-setreni-TALIS-2013 
nejpotřebnější. Účast učitelů v ČR na dalším vzdělávání v tématech dotýkajících se oblastí, v nichž se cítí méně zdatní, byla o poznání menší než v mezinárodním průměru (viz tabulka 5).

Tabulka 5

Podíl učitelů, kteří se v průběhu 12 měsíců před sběrem dat účastnili vzdělávání zaměřeného na uvedená témata ( $v \%)$

\begin{tabular}{llc}
\hline & ČR & Průměr TALIS \\
\hline Pedagogické kompetence pro výuku konkrétních předmětů & 51 & 68 \\
Přístupy k individualizovanému učení & 23 & 41 \\
Postupy hodnocení výsledků vzdělávání a úspěšnosti žáků & 29 & 57 \\
Výuka žáků se speciálními vzdělávacími potřebami & 24 & 32 \\
\hline
\end{tabular}

Pozn. Převzato z TALIS 2013.

Při posuzování vztahů mezi dalším vzděláváním v jednotlivých obsahových oblastech a subjektivně vnímanou zdatností učitelů se ukázalo, že učitelé, kteří se v posledních 12 měsících před sběrem dat zúčastnili vzdělávání zaměřeného na některou z uvedených pěti nejnavštěvovanějších oblastí, dosahovali v indexu celkové subjektivně vnímané zdatnosti i v indexu subjektivně vnímané zdatnosti v motivování a zapojování žáků hodnot srovnatelných s průměrem ČR. Nadprůměrných hodnot v obou indexech však dosáhli učitelé, jejichž profesní vzdělávání zahrnovalo jiné, méně běžné obsahové oblasti. Toto zjištění je v zásadě v souladu s údajem o pozitivní souvislosti mezi sebehodnocením zdatnosti v motivování žáků a počtem různých druhů obsahu absolvovaného dalšího profesního vzdělávání (Kašparová et al., 2014b, s. 48).

Navzdory tomu, že další profesní vzdělávání zaměřené na nejčastěji volené obsahové oblasti zřejmě učitelům př́liš nepomáhá posílit sebevědomí v tom, v čem se necítí silní, byl dopad profesního vzdělávání na výuku hodnocen učiteli v ČR napříč různými obsahovými oblastmi značně pozitivně a srovnatelně s mezinárodním průměrem.

Subjektivně vnímaná zdatnost učitelů s ohledem na jejich účast v dalším profesním vzdělávání dle formy, v jaké se realizuje

Vedle obsahu se lze podívat na to, jakou formou se učitelé v ČR nejčastěji vzdělávají. Nejobvyklejší formou dalšího profesního vzdělávání jsou v ČR kurzy nebo semináře, kterých se v posledních 12 měsících před sběrem dat 
účastnilo $70 \%$ učitelů. Druhou nejčastější formou je zapojení do formálního systému mentoringu nebo vzájemných hospitací či konzultací ve škole (34 \%). Účast učitelů v ČR v těchto dvou formách dalšího profesního vzdělávání je srovnatelná s mezinárodním průměrem.

Zapojení do jiných forem dalšího profesního vzdělávání se v ČR týká méně než čtvrtiny učitelů a s výjimkou exkurzí ve firmách, veřejných či nevládních institucích, kvalifikačních programů a průběžných vzdělávacích kurzů mimo školu je podstatně nižší než v mezinárodním průměru. Přibližně dvakrát nižší je v ČR účast učitelů na pedagogických konferencích, jejich zapojení do skupiny učitelů orientované na profesní rozvoj svých členů a do individuálního či skupinového výzkumu (tabulka 6).

Tabulka 6

Podíl učitelů, kteří se v průběhu 12 měsíců před sběrem dat účastnili vybraných forem profesního vzdělávání ( $\mathrm{\%}$ )

\begin{tabular}{lcc}
\hline & ČR & Průměr TALIS \\
\hline Účast na pedagogických konferencích & 22 & 44 \\
$\begin{array}{l}\text { Zapojení do skupiny učitelů orientované na profesní rozvoj } \\
\text { svých členů }\end{array}$ & 17 & 37 \\
Zapojení do individuálního či skupinového výzkumu & 16 & 31 \\
\hline
\end{tabular}

Pozn. Převzato z TALIS 2013.

Národní zpráva (Kašparová et al., 2014a) přitom ukázala, že se zapojením učitelů do dvou posledně jmenovaných forem profesního rozvoje v ČR souviselo častější (deklarované) využívání aktivizujících metod výuky, které byly v šetření TALIS sledovány (práce žáků v malých skupinách, práce žáků s ICT při výuce či na projektech a práce žáků na projektech, jejichž dokončení trvá alespoň týden). Doplňme, že ze sledovaných zemí uvedlo Polsko a Estonsko naopak nadprůměrné zapojení učitelů do těchto dvou forem dalšího profesního vzdělávání. ${ }^{12}$

V šetření TALIS bylo dále sledováno, zda další profesní vzdělávání učitelů obsahovalo prvky, o nichž lze na základě dosavadních výzkumů předpokládat, že zvyšují jeho efektivitu (OECD, 2013, s. 25). Zde lze konstatovat, že v ČR

12 Do skupiny učitelů zaměřené na profesní rozvoj svých členů bylo zapojeno $41 \%$ učitelů v Polsku a $51 \%$ v Estonsku, do individuálního či skupinového výzkumu pak $38 \%$ učitelů v Polsku a $34 \%$ v Estonsku. 
je zejména účast učitelů ze stejné školy či předmětové aprobace a učení se formou spolupráce či výzkumné činnosti oproti mezinárodnímu průměru méně časté (tabulka 7). Přitom sousední Polsko zaznamenalo výrazně vyšší výskyt všech těchto prvků v profesním vzdělávání učitelů, než jaký byl zaznamenán u nás.

Tabulka 7

Podíl učitelu, kteří uvedli, že další profesní vzdělávání obsahovalo uvedené prvky ve většině či všech aktivitách a v žádné aktivitě ( $v \%)$

\begin{tabular}{lccccc}
\hline & \multicolumn{2}{c}{ Česká republika } & \multicolumn{2}{c}{ Průměr TALIS } \\
\cline { 2 - 6 } & v žádné & $\begin{array}{c}\text { ve všech } \\
\text { či většině }\end{array}$ & v žádné & $\begin{array}{c}\text { ve všech } \\
\text { či většině }\end{array}$ \\
\hline $\begin{array}{l}\text { Účast skupiny kolegů z mé školy/předmětové } \\
\text { aprobace }\end{array}$ & 33 & 23 & 17 & 40 \\
\hline $\begin{array}{l}\text { Učení se formou spolupráce či výzkumné činnosti } \\
\text { s dalšími učiteli }\end{array}$ & 45 & 16 & 31 & 26 \\
\hline $\begin{array}{l}\text { Vzdělávání po delš́ časové období (rozloženo } \\
\text { do více týdnů nebo měsíců) }\end{array}$ & 57 & 16 & 48 & 20 \\
\hline $\begin{array}{l}\text { Př́ležitosti pro využití aktivních metod učení } \\
\text { (nejen poslouchání výkladu) }\end{array}$ & 23 & 29 & 21 & 33 \\
\hline
\end{tabular}

Pozn. Převzato z TALIS 2013.

Podobně jako u obsahového zaměření vzdělávacích aktivit (viz výše) jsme analyzovali souvislost mezi účastí učitelů v ČR v jednotlivých formách dalšího vzdělávání a jejich subjektivně vnímanou zdatností. ${ }^{13} \mathrm{~K}$ tomu jsme využili porovnání průměrných hodnot indexu subjektivně vnímané zdatnosti v motivování a zapojování žáků do výuky u učitelů, kteří se jednotlivých typů aktivit účastnili a neúčastnili (tabulka 8). Obdobné výsledky byly zjištěny při porovnávání hodnot indexu celkové subjektivně vnímané zdatnosti mezi účastníky a neúčastníky různých vzdělávacích aktivit.

13 Šetření TALIS jakožto jednorázové dotazníkové šetření neumožňuje vyvozovat závěry o kauzálních vztazích. Nelze tedy s jistotou říci, zda účast v určitých formách profesního vzdělávání vedla ke zvýšení subjektivně vnímané zdatnosti učitelů, nebo zda učitelé, kteří se cítí být zdatnější, jsou otevřeni účasti i v méně běžných formách profesního vzdělávání, a tedy schopni absolvovat jejich širší škálu. 
Tabulka 8

Subjektivně vnímaná zdatnost učitelů v motivování a zapojování žáků do výuky podle jejich účasti v různých formách dalšího vzdělávání

\begin{tabular}{|c|c|c|c|}
\hline \multirow[b]{2}{*}{ Formy vzdělávacích aktivit } & \multicolumn{3}{|c|}{$\begin{array}{c}\text { Index subjektivně vnímané } \\
\text { zdatnosti v motivování a zapojování } \\
\text { žáků do výuky }\end{array}$} \\
\hline & Účastnili se & Neúčastnili se & Rozdíl \\
\hline Kurzy či semináře (70%) & 9,57 & 9,43 & 0,14 \\
\hline $\begin{array}{l}\text { Mentoring nebo vzájemné hospitace či konzultace } \\
\text { v rámci formálního systému ve škole ( } 34 \%)\end{array}$ & 9,73 & 9,42 & $\mathbf{0 , 3 1}$ \\
\hline Pedagogické konference nebo semináře (22 \%) & 9,77 & 9,46 & $\mathbf{0 , 3 1}$ \\
\hline $\begin{array}{l}\text { Exkurze v komerčních prostorách, veřejných či } \\
\text { nevládních organizacích }(18 \%)\end{array}$ & 9,72 & 9,48 & 0,24 \\
\hline Kvalifikační program (18 \%) & 9,62 & 9,51 & 0,11 \\
\hline $\begin{array}{l}\text { Účast ve skupině učitelů zaměřené na profesní rozvoj } \\
\text { svých členů }(17 \%)\end{array}$ & 9,79 & 9,47 & 0,32 \\
\hline Individuální nebo skupinový výzkum (16\%) & 9,98 & 9,44 & 0,54 \\
\hline Průběžné vzdělávací kurzy (14%) & 9,80 & 9,48 & 0,32 \\
\hline Exkurze či hospitace v jiných školách (14 \%) & 9,84 & 9,47 & 0,37 \\
\hline
\end{tabular}

Pozn. Převzato z TALIS 2013, vlastní výpočty autorů.

Pozn. V závorkách jsou uvedeny podíly učitelů, kteří v posledních 12 měsících před sběrem dat absolvovali danou aktivitu. Statisticky významné rozdíly v průměrných hodnotách indexu mezi účastníky a neúčastníky uvedených aktivit jsou vyznačeny tučně.

Je patrné, že učitelé, kteří se účastnili kurzů či seminářů (tj. nejnavštěvovanějšího typu vzdělávacích aktivit), se v sebehodnocení vlastní zdatnosti statisticky významně neliší od učitelů, kteří se jich neúčastnili. Absolvování jiných typů aktivit s výjimkou exkurzí mimo školy a - možná poněkud překvapivě - kvalifikačních programů se naopak pojí se statisticky významně vyšší subjektivně vnímanou zdatností. Statisticky významně vyšší hodnoty indexu subjektivně vnímané zdatnosti v oblasti motivování žáků a jejich zapojování do výuky zaznamenali také učitelé, jejichž další profesní vzdělávání obsahovalo ve většině nebo všech absolvovaných aktivitách dva nebo více prvků uvedených v tabulce 7 , které mají podle dosavadních výzkumů zvyšovat jeho efektivitu (ve srovnání s učiteli, jejichž profesní vzdělávání tolik efektivních prvků neobsahovalo). 


\section{Bariéry účasti v dalším profesním vzdělávání}

Při interpretaci zjištění o účasti učitelů v dalším profesním vzdělávání je třeba mít na paměti, že efektivnější aktivity dalšího vzdělávání, které jsou zacíleny na méně obvyklé obsahy a probíhají méně běžnými formami, mohou být pro učitele relativně méně dostupné. Při volbě vzdělávacích aktivit si učitelé vždy vybírají z určité nabídky, která je omezená. V šetření TALIS 2013 uvedlo $26 \%$ učitelů v ČR, že jim v účasti v profesním vzdělávání brání absence vhodné nabídky profesního vzdělávání (v mezinárodním průměru tak uvedlo $39 \%$ učitelů).

Kromě adekvátní nabídky aktivit profesního vzdělávání (tj. cílených a reagujících na potřeby učitelů co do obsahu i formy) mohou být učitelům i jinak nastavovány více či méně optimální podmínky k profesnímu vzdělávání. Šetření TALIS v této souvislosti poukazuje na to, že potřebné další vzdělávání nemůže řada učitelů v ČR skloubit s pracovním rozvrhem (45\%), významná část jich také postrádá motivaci (38\%), nebo je považuje za příliš nákladné (36\%).

Z hlediska zvyšování subjektivní zdatnosti učitelů lze za nejkritičtější bariéru považovat nedostatečnou motivaci $\mathrm{k}$ dalšímu vzdělávání. Učitelé, kteří se necítí být motivováni dále se vzdělávat a pracovat na svém profesním rozvoji, mohou být zároveň méně motivováni zlepšovat svoji výuku ve tř́dách. Kromě efektivního vedení učitelů, finanční podpory a dostatečného časového prostoru je pro motivaci učitelů účastnit se dalšího vzdělávání důležitá i samotná nabídka vzdělávacích aktivit. Šetření TALIS ukázalo, že učitelé, kterým nevyhovuje dostupná nabídka, jsou výrazně méně motivováni účastnit se dalšího vzdělávání. ${ }^{14}$

\subsection{Podmínky pro učitele ve školách jako motivující prostředek}

$\mathrm{V}$ této části se zaměříme na otázku, jak souvisí subjektivně vnímaná zdatnost a spokojenost učitelů s pracovními podmínkami v konkrétních školách. Nejprve poukážeme na zajímavé vztahy mezi subjektivně vnímanou zdatností učitelů resp. jejich spokojeností s pracovním prostředím a některými charakteristikami školního klimatu. Ve shodě s národní i analytickou zprávou z šetření TALIS budeme tyto charakteristiky označovat atmosféra

$14 \mathrm{Z}$ učitelů, kteří rozhodně souhlasí nebo souhlasí s tím, že neexistuje vhodná nabídka profesního vzdělávání, jich 54 \% není motivováno se dále vzdělávat. Naproti tomu z učitelů, kteří nevnímají nabídku dalšího vzdělávání jako nevhodnou, přiznává nedostatek motivace 32 \%. 
a spolupráce ve škole. Poté porovnáme, nakolik jsou ve školách v ČR oproti školám v mezinárodním průměru uplatňovány různé postupy, které mohou učitelům pomoci rozvíjet jejich dovednosti, a posoudíme, jak mohou školy vytvářet pro učitele optimální podmínky.

\section{Atmosféra a spolupráce ve škole}

Analytická zpráva z šetření TALIS 2013 (Kašparová et al., 2014b) dokládá, že se subjektivně vnímanou zdatností učitelů souvisí řada ukazatelů na úrovni školy. V ČR byla především zjištěna jako statisticky významná pozitivní souvislost mezi subjektivně vnímanou zdatností učitelů ve všech jejích dílčích oblastech a bližší profesní spoluprací učitelư ${ }^{15}$, jakož i atmosférou ve třídách (až na souvislost mezi subjektivně vnímanou zdatností ve využívání alternativních vyučovacích metod a atmosférou ve třídě byly uvedené souvislosti vyhodnoceny jako vysoce významné). Kromě toho byla vysoká pozitivní souvislost shledána i mezi subjektivně vnímanou zdatností v oblasti ř́zení třídy žáků a vztahy žáků a učitelů ve škole. Vztahy učitelů a žáků, atmosféra ve tř́idách, ale též míra profesní spolupráce učitelů zároveň pozitivně souvisejí se spokojeností učitelů s pracovním prostředím a ta vysoce pozitivně souvisí se spokojeností učitelů s jejich povoláním.

Dle očekávání si v ČR učitelé ve školách, kde spolu učitelé intenzivněji spolupracují, také mezi sebou častěji poskytují zpětnou vazbou. Přitom učitelé, kteří dostávají zpětnou vazbu nejen od vedení školy, ale také od ostatních učitelů, vnímají svou vlastní zdatnost v oblasti používání vyučovacích postupů a v oblasti motivování žáků jako vyšší a také jsou spokojenější s pracovním prostředím. Tito učitelé zároveň pocitovali, že zpětná vazba, které se jim dostalo, měla pozitivnější dopad na kvalitu výuky i jejich vlastní motivaci, než jaký byl zaznamenán u učitelů dostávajících zpětnou vazbu pouze od vedení školy, a v souladu s tím též uváděli, že využívají pestřejší paletu výukových postupů. Naopak učitelé, kteří souhlasili s výrokem, že zpětná vazba se v jejich škole provádí víceméně pouze za účelem splnění administrativních požadavků (tj. jen jako „formalita“ vykonávaná pravděpodobně vedením školy), byli významně méně spokojeni s pracovním prostředím než ti, kteří s tímto výrokem nesouhlasili.

15 K bližší profesní spolupráci je v šetření TALIS řazena týmová výuka společně s jinými učiteli v téže třídě; pozorování výuky ostatních učitelů a poskytování zpětné vazby k jejich práci; zapojování se do společných aktivit napříč třídami a věkovými skupinami (např. do projektů); a společná práce $s$ kolegy na svém profesním rozvoji. 
Výše uvedené souvislosti lze doplnit zjištěním znázorněným v tabulce 9, že až na týmovou výuku se do jednotlivých forem bližší profesní spolupráce učitelé v ČR zapojují o něco aktivněji než v mezinárodním průměru (přestože lze konstatovat, že v Polsku jsou podíly učitelů, kteří se alespoň občas zapojují do forem bližší profesní spolupráce, ještě vyšší).

Tabulka 9

Podíl učitelů, kteří se účastní uvedených druhů profesní spolupráce (\%)

\begin{tabular}{lcccc}
\hline & \multicolumn{2}{c}{ Česká republika } & \multicolumn{2}{c}{ Průměr TALIS } \\
\cline { 2 - 6 } & nikdy & $\begin{array}{c}\text { alespoň } \\
\text { 2x ročně }\end{array}$ & nikdy & $\begin{array}{c}\text { alespoň } \\
\text { 2x ročně }\end{array}$ \\
\hline $\begin{array}{l}\text { Zapojují se do společných aktivit např́íc třídami } \\
\text { a věkovými skupinami (např. do projektů). }\end{array}$ & 8 & 65 & 21 & 55 \\
$\begin{array}{l}\text { Společně s kolegy pracují na svém profesním rozvoji. } \\
\text { Pozorují výuku ostatních učitelů a poskytujíjim }\end{array}$ & 8 & 72 & 16 & 63 \\
$\begin{array}{l}\text { zpětnou vazbu. } \\
\text { Vyučují týmově společně s jinými učiteli v téže třídě. }\end{array}$ & 58 & 37 & 45 & 34 \\
\hline
\end{tabular}

Pozn. Převzato z TALIS 2013.

Vedle spolupráce učitelů ve škole je v ČR nadprůměrný také podíl učitelů, kteří získávají zpětnou vazbu od dalších učitelů (53\% oproti $42 \%$ v mezinárodním průměru). Zapojení učitelů do bližší profesní spolupráce přitom souvisí nejen $s$ vyšší mírou poskytování zpětné vazby mezi učiteli a lepším hodnocením dopadu takové zpětné vazby na výuku, ale také s vyšším pocitem spoluzodpovědnosti za vedení školy (Kašparová et al., 2014b, s. 19). Jak spolupráci učitelů, tak i poskytování zpětné vazby a atmosféru spoluzodpovědnosti za výsledky školy lze tedy považovat za různé aspekty klimatu vzájemné podpory a spolupráce ve škole, které se pojí s lepším sebehodnocením zdatnosti učitelů.

\section{Mentoring a zaškolování učitelů}

Mezinárodní zpráva z šetření (OECD 2014b, s. 418, tabulka 7.10) dále dokládá, že v ČR pozitivně souvisí celková subjektivně vnímaná zdatnost učitelů s jejich účastí v mentoringu a/nebo ve vzájemných hospitacích a konzultacích $\mathrm{s}$ kolegy $\mathrm{v}$ rámci formálně nastaveného systému práce ve škole. Souvislost samotné účasti učitelů v systému mentoringu (at' již jako mentor či mentorovaný) se subjektivně vnímanou zdatností učitelů se však neprokázala a podíl 
učitelů zapojených do systému mentoringu je výrazně podprůměrný (tabulka 10).

Tabulka 10

Podíl učitelů, kteří mají pověřeného mentora a kteří pưsobí jako mentoři (v \%) ${ }^{16}$

\begin{tabular}{lccc}
\hline & ČR & Průměr TALIS & Polsko \\
\hline V současné době mají přiděleného mentora, který jim pomáhá. & 4 & 15 & 12 \\
Působí jako pověření mentoři jednoho nebo více učitelů. & 8 & 14 & 15 \\
\hline
\end{tabular}

Pozn. Převzato z TALIS 2013.

V šetření TALIS 2013 byl též zjištóován pohled ředitelů a z těch v ČR pouze třetina uvedla, že nikdo $\mathrm{z}$ učitelů ve škole nemá přístup k systému mentoringu. Přitom jen $4 \%$ ředitelů se domnívají, že mentoring není vůbec př́inosný pro zlepšování výsledků žáků a dalších $23 \%$ jeho přínos ohodnotilo jako malý. Oproti tomu $96 \%$ učitelů uvedlo, že mentoring má středně velký či velký význam v podpoře méně zkušených učitelů. Analytická zpráva z šetření TALIS 2013 proto s odkazem na Píšovou a Duschinskou (2011) uvádí, že „V České republice převažuje vnímání mentoringu jako formy podpory začínajících a nových učitelů, nikoli jako systému, který doprovází učitele v průběhu celé kariéry“ (Kašparová et al., 2014b, s. 71). V tomto ohledu by tedy stálo za to směřovat k přehodnocení stávající praxe.

Lze doplnit, že v České republice je v souladu se zjištěními o relativně nízké účasti učitelů v intenzivnějších formách profesního vzdělávání a v mentoringu též v mezinárodním srovnání výrazně podprůměrná účast ředitelů na profesním vzdělávání v rámci odborné skupiny, mentoringu nebo výzkumné skupiny. ${ }^{17}$ To může mít za následek menší potenciál k sebereflexi ředitelů, a tudíž méně flexibilní zavádění pozitivních změn ve vedení školy a v řízení vzdělávacího procesu.

Jinou formu podpory nově nastupujících učitelů představuje tzv. indukce (uvádění do praxe, $\mathrm{v}$ šetření TALIS byl $\mathrm{v}$ tomto smyslu použit termín

16 Nesoulad mezi podílem mentorů a mentorovaných je možné přičíst tomu, že školy v ČR často slučují více úrovní vzdělávání (např. 1. a 2. stupeň ZŠ nebo nižší a vyšší ročníky víceletých gymnázií).

17 Tento podíl činí $28 \%$ ředitelů v ČR oproti $51 \%$ v mezinárodním průměru; výrazně vyšší účast než ředitelé v ČR uvedli ze sledovaných zemí ředitelé na Slovensku (64 \%), v Estonsku (54\%) a ve Finsku (48 \%), v Polsku tento podíl činí $31 \%$. 
zaškolování). I zde lze konstatovat, že formální systémy zaškolování mají v ČR poměrně nízké zastoupení (62\% učitelů působí ve školách, v nichž není k dispozici žádný formální zaškolovací program). Naopak neformální zaškolovací aktivity může ve školách využívat $81 \%$ učitelů. V ČR učitelé, kteří se ve svém prvním učitelském zaměstnání účastnili neformálních zaškolovacích aktivit, vyjádřili o něco větší spokojenost v zaměstnání než ti, kteří se takových aktivit neúčastnili. Učitelé, kteř́i se účastnili formálních zaškolovacích aktivit, uvedli zase o něco lepší sebehodnocení vlastní zdatnosti. Ačkoliv je tedy formální i neformální zaškolování důležité, pro podporu subjektivně vnímané zdatnosti se jeví jako důležitější zařazení formálních zaškolovacích programů.

\section{Hodnocení učitelů a jeho dopady}

Kromě spolupráce učitelů, vzájemného poskytování zpětné vazby, zaškolování nových učitelů a spoluodpovědnosti učitelů za chod školy je z hlediska pedagogického řízení školy důležité, zda je hodnocení učitelů provázáno s dalšími opatřeními, která mohou pomoci zlepšit identifikované nedostatky. ČR je zemí s druhým nejvyšším podílem učitelů (65 \%), kteří nesouhlasí s tvrzením, že by hodnocení učitelů bylo prováděno pouze s cílem splnit administrativní požadavky. Přitom u nás byla zjištěna silná pozitivní souvislost jak mezi spokojeností učitelů v zaměstnání a jejich názorem, že zpětná vazba není prováděna pouze za účelem splnění administrativních požadavků, tak i mezi spokojeností učitelů v zaměstnání a jejich názorem, že zpětná vazba má vliv na to, jak učitelé vyučují ve třídách (OECD 2014b, s. 421, tabulka 7.13).

Podíváme-li se na konkrétní hodnocení dopadů zpětné vazby na učitele v ČR, vede (podle jejich výpovědí v šetření TALIS 2013) poskytnutá zpětná vazba především $\mathrm{k}$ pozitivním změnám $\mathrm{v}$ jejich sebedůvěře (středně velkou či velkou změnu uvedlo $62 \%$ učitelů), dále pak v oblasti veřejného uznání jejich práce od vedení školy či kolegů (57 \%), v uspokojení z vykonávané práce (56 \%) a v motivaci (55\%). Nadpoloviční podíl učitelů také uvedl středně velkou či velkou pozitivní změnu v oblasti výukových postupů (53 \%) a v oblasti využívání hodnocení žáků (51 \%). Středně velké či velké pozitivní změny týkající se kariérního postupu, platu a objemu profesního vzdělávání však uvedlo již jen $30 \%$ a méně učitelů (což je, s výjimkou změny v platu, méně než v mezinárodním průměru). Přitom učitelé, kteří uvedli, že $\mathrm{v}$ důsledku poskytnuté zpětné vazby došlo ke střední nebo velké pozitivní změně v kterékoli z šesti oblastí řazených do kategorie změn v postavení učitele ( $\mathrm{tj}$. v kariérním postupu, platu, objemu profesního vzdělávání, veřejně vyjádřeném 
uznání, v roli v iniciativách zaměřených na rozvoj školy a v pracovních povinnostech ve škole), jsou ve svém zaměstnání spokojenější a zároveň se cítí být zdatnější. V tomto ohledu poznamenejme, že 93 \% ředitelů v ČR uvedlo, že efektivita jejich práce je do určité či značné míry omezena nedostatečným rozpočtem školy a finančních zdrojů (v mezinárodním průměru byl tento podíl $80 \%$ ) a $82 \%$ jich pocitujue jako určité či značné omezení velkou pracovní zátěž a odpovědnost ( $\mathrm{v}$ mezinárodním průměru byl tento podíl $72 \%$ ). Ředitelé v ČR tedy možnosti svého působení ve škole vnímají jako omezené, což se může odrazit na míře návazných kroků, ke kterým po hodnocení učitelů přistupují.

\section{Shrnutí, diskuse, závěry}

V tomto textu jsme si kladli za cíl představit podstatná zjištění z šetření TALIS 2013 týkající se subjektivně vnímané zdatnosti učitelů a jejich spokojenosti v zaměstnání v kontextu jejich profesního vzdělávání a vybraných charakteristik klimatu, resp. kultury školy. Považovali jsme za užitečné nejprve představit, jaké důvody vedly ke zrodu šetření TALIS, a informovat o jeho kontinuitě a postupu realizace. Poté jsme přiblí̌žli koncepční rámec šetření a další důležitá teoretická a empirická východiska, přičemž jsme se soustředili na témata, která se váží $\mathrm{k}$ výsledkům prezentovaným $\mathrm{v}$ tomto textu. $\mathrm{V}$ části věnované zjištěním jsme poukázali na relativně nízkou subjektivně vnímanou zdatnost učitelů v ČR a nadprůměrně často se vyskytující pocit, že je učitelské povolání nevýhodné a ve společnosti nevážené.

Uvedli jsme, že přes nízkou subjektivně vnímanou zdatnost učitelů v ČR jich naprostá většina deklarovala, že je se svým výkonem ve škole spokojena. Upozornili jsme na zajímavou skutečnost, že (oproti mezinárodnímu průměru, jakož i oproti ostatním sledovaným oblastem) relativně nízká subjektivně vnímaná zdatnost učitelů v ČR v oblasti motivování žáků a jejich aktivního zapojování do výuky, ale také ve využívání alternativních vyučovacích postupů se př́liš neodráží ve volbě tematických oblastí, v nichž učitelé cítí potřebu se vzdělávat a v nichž se skutečně vzdělávají, a že navzdory tomuto nesouladu hodnotí učitelé dopady profesního vzdělávání napříč tematickými oblastmi značně pozitivně. S nízkou subjektivně vnímanou zdatností v uvedených oblastech naopak koresponduje podprůměrná míra deklarovaného využívání aktivizujících metod výuky v ČR (viz Kašparová et al., 2014, s. 44, graf 30). Jedním z možných vysvětlení této skutečnosti je, že učitelé v ČR nepovažují motivování žáků ani využívání alternativních vyučovacích metod za stěžejní 
součást svého působení, a proto jim nízké sebehodnocení v těchto ohledech nemusí bránit vykonávat práci tak, aby se svým výkonem byli spokojeni. Co se týče hodnocení dalšího profesního vzdělávání, kterého se učitelé účastní, oceňují při něm zřejmě jiné dopady, než je zvyšování subjektivně vnímané zdatnosti v uvedených oblastech. Rovněž preferované obsahy dalšího vzdělávání, v nichž vedle ICT dovedností dominuje rozšiřování znalostí a dovedností potřebných pro výuku předmětů, napovídají, že učitelé v ČR se vnímají být spíše vyučujícími konkrétních předmětů, jejichž úkolem je zprostředkování příslušného vzdělávacího obsahu. Ověření tohoto předpokladu však šetření TALIS neumožňuje a vyžadovalo by provedení samostatného výzkumu.

Významně vyšší sebehodnocení zdatnosti v oblasti motivování žáků a jejich zapojování do výuky bylo zaznamenáno u učitelů, kteří se zúčastnili méně obvyklých aktivit dalšího vzdělávání co do obsahu i formy (které bývají často navštěvované vedle těch nejčastěji využívaných, tedy záleží i na pestrosti). Data z šetření TALIS naznačují, že profesní vzdělávání zaměřené na nejčastěji volené obsahové oblasti, které v zásadě odpovídají deklarovaným potřebám dotazovaných učitelů, není příliš účinné pro zvyšování jejich vnímané zdatnosti. S lepším sebehodnocením zdatnosti učitelů nesouvisí ani jejich účast v nejběžnějších formách vzdělávacích aktivit (kurzech a seminářích) a efektivnější se jeví být formy dalšího vzdělávání, které zahrnují účast většího počtu učitelů ze stejné školy nebo se stejnou aprobací, probíhají delší dobu a vyžadují využití aktivních metod učení (nejen poslouchání přednášejícího). $\mathrm{K}$ takovým aktivitám patří například průběžné vzdělávací kurzy, individuální nebo skupinový výzkum, pedagogické konference, vzájemné hospitace nebo mentoring či konzultace $\mathrm{s}$ kolegy $\mathrm{v}$ rámci formálního systému ve škole. Jelikož dotazníkové šetření typu TALIS není schopno určit směr vzájemného působení mezi proměnnými, mohou uvedené vztahy v praxi fungovat i obráceně, tzn. učitelé, kteří se cítí zdatnější, si mohou volit pestřejší škálu různých druhů obsahu dalšího vzdělávání včetně těch s méně běžným obsahovým i formálním zaměřením.

Z šetření TALIS dále vyplynulo, že zapojení učitelů v ČR do aktivit profesního vzdělávání zahrnujících účast kolegů z jejich školy nebo se stejnou předmětovou aprobací a učení se formou spolupráce či výzkumné činnosti s dalšími učiteli (tj. efektivní prvky profesního vzdělávání) bylo o poznání nižší než v mezinárodním průměru. Přestože byla zaznamenána nadprůměrná míra spolupráce učitelů v rámci školy a poskytování zpětné vazby nejen od vedení školy, ale i od kolegů učitelů, není tento potenciál příznivého školního klimatu 
dostatečně využíván k realizaci efektivnějšího profesního vzdělávání. K tomu lze doplnit, že i profesní klima ve školách, atmosféra ve třídách a vztahy učitelů a žáků byly hodnoceny značně pozitivně a v ČR nejnižší podíl učitelů ze všech zemí uvedl, že by rádi přešli na jinou školu, kdyby to bylo možné.

Přesto se ukazuje jako vysoce žádoucí dále podporovat zejména bližší profesní spolupráci učitelů a poskytování vzájemné zpětné vazby, ale také obecně dobrou atmosféru ve škole, nebot' byly identifikovány výrazné souvislosti těchto jevů se subjektivně vnímanou zdatností učitelů.

Kromě dobrých kooperativních vztahů učitelů navzájem a vztahů učitelů a žáků je přitom důležitá i spolupráce mezi učiteli a vedením školy. Učitelé vnímající ve své škole vyšší spoluodpovědnost aktérů za její fungování bývají intenzivněji zapojeni do profesní spolupráce se svými kolegy a vyšší podíl jich také odpověděl, že dostává zpětnou vazbu ke své práci od svých kolegů učitelů. Učitelé, kteří mají možnost se spolupodílet na rozhodování o záležitostech školy, jsou navíc častěji názoru, že si jejich povolání společnost váží. Zároveň tito učitelé ve vyšší míře uvedli, že zpětná vazba získaná (mimo jiné) od ostatních učitelů měla pozitivní dopad na kvalitu jejich výuky a na jejich motivaci k práci (Kašparová et al., 2014b). Přitom již v Národní zprávě (Kašparová et al., 2014a) bylo uvedeno, že ve 20 zemích včetně ČR souvisí pozitivně př́ležitosti, jež mají zaměstnanci školy $\mathrm{k}$ tomu, aby rozhodovali o školních záležitostech, s celkovou subjektivně vnímanou zdatností učitelů.

Jako nedostatek lze v ČR označit relativně nízké provázání hodnocení práce učitelů ve školách s jejich účastí na profesním vzdělávání, nízkou účast učitelů v mentorských programech, méně častou nabídku formálních zaškolovacích programů pro začínající či nové učitele, ale také (dle výpovědí ředitelů) nedostatečné finanční prostředky, které má škola k dispozici, př́lišnou administrativní zátěž ředitelů v ČR a jejích nízké zapojení do dalšího vzdělávání v rámci odborné skupiny, mentoringu nebo výzkumné skupiny (tj. formy profesního rozvoje, která se jeví jako účinná a může podpořit sebereflexi jejich práce). Rezervy však lze spatřovat i v nabídce programů profesního vzdělávání pro učitele (srov. k tomu také Starý et al., 2012, s. 109), která v současné podobě nemusí vždy odpovídat jejich potřebám a nemusí obsahovat žádoucí formy a obsahy, nebo v motivování učitelů k účasti ve vzdělávání, které jim může být nejvíce přínosné (např̀ orientované na slabá místa, zahrnující efektivní prvky či formy apod.). Do těchto oblastí by tudíž bylo vhodné směřovat jak koncepční práci, tak odpovídající finanční a další podporu. 


\section{Literatura}

Balaštíková, V., Blatný, M., \& Kohoutek, T. (2004). Aspekty sebepojetí jako determinanty výběru strategií zvládání u adolescentů. Československá psychologie, 48(5), 410-415.

Bandura, A. (1986). Social foundations of thought and action: A social cognitive theory. Englewood Cliffs: Prentice-Hall.

Bandura, A. (1995). Self-efficacy in changing societies. Cambridge: Cambridge University Press.

Centrum pro výzkum veřejného mínění, Sociologický ústav AV ČR (2013). Prestiž povolání - červen 2013 (Tisková zpráva). Dostupné z http://cvvm.soc.cas.cz/media/com_ form2content/documents/c1/a7054/f3/eu130903.pdf

Dvořák, D., Starý, K., \& Urbánek, P. (2015). Malá škola po pěti letech: Proměny školy v době reformy. Pedagogická orientace, 25(1), 9-31.

Factum Invenio (2009). Analýza předpokladů a vzdělávacích potřeb pedagogických pracovníků pro zkvalitňování jejich práce. Praha: MŠMT.

Garet, M. S., Porter, A. C., Desimone, L., Birman, B. F., \& Yoon, K. S. (2001). What makes professional development effective? Results from a national sample of teachers. American Educational Research Journal, 38(4), 915-945.

Gavora, P. (2009). Profesijná zdatnost' vnímaná učitelom. Adaptácia výskumného nástroja. Pedagogická revue, 61(1-2), 19-37.

Gavora P., \& Majerčíková, J. (2012). Vnímaná zdatnost' (self-efficacy) učitela: Oblast' vyučovania a oblast' spolupráce s rodičmi. Pedagogická orientace, 22(2), 205-221.

Horáková Hoskovcová, S. (2006). Self-efficacy in preschool children. Studia psychologica, 48(2), 175-182.

Janík, T., Slavík, J., Mužík, V., Trna, J., Janko, T., Lokajíčková, V., ... Zlatníček, P. (2013). Kvalita (ve) vzdělávání: obsahově zaměřený přístup ke zkoumání a zlepšování výuky. Brno: Masarykova univerzita.

Janoušek, J. (2000). Sociálně kognitivní teorie Alberta Bandury. Československá psychologie, 36(5), 385-397.

Kašparová, V. (2013). Zpráva o kvalitě provedení šetření TALIS 2013. Praha: ČŠI.

Kašparová, V., Boudová, S., Ševců, M., \& Soukup, P. (2014a). Národní zpráva šetření TALIS 2013. Praha: С̌ŠI.

Kašparová, V., Holečková, A., Hučín, J., Janík, T., Najvar, P., Píšová, M., ... Ševců, M. (2014b). Analytická zpráva z šetření TALIS 2013. Praha: ČŠI.

Křeménková, L., \& Novotný, J. S. (2010). Profil motivační struktury učitele. In I. Moravcová \& J. Veteška (Eds.), Aktuální otázky pedagogiky, psychologie a výchovného poradenství VI (s. 65-73). Pardubice: Univerzita Pardubice.

Majerčíková, J., \& Gavora, P. (2013). Vnímaná zdatnost' (self-efficacy) učitela spolupracovat' s rodičmi: konštrukcia výskumného nástroja. Pedagogika, 63(2), 128-146.

Mareš, J. (2013). Nevhodné chování učitelů k žákům a studentům. Studia paedagogica, 18(1), 7-36.

McKinsey, \& Company (2010). Klesající výsledky českého základního a středního školství: fakta a řešení. Praha: McKinsey \& Company.

Milson, A. J. (2003). Teachers' sense of efficacy for the formation of students' character. Journal of Research in Character Education, 1(2), 90-106. 
OECD (2005). Teachers matter: Attracting, developing and retaining effective teachers. Paris: OECD Publishing.

OECD (2013). Teaching and learning international survey TALIS 2013 conceptual framework. Paris: OECD Publishing.

OECD (2014a). TALIS 2013 Technical report. Paris: OECD Publishing.

OECD (2014b). TALIS 2013 Results: An international perspective on teaching and learning. Paris: OECD Publishing.

OECD (2014c). New insights from TALIS 2013: Teaching and learning in primary and upper secondary education. Paris: OECD Publishing.

OECD (2014d). Education at a glance 2014: OECD indicators. Paris: OECD Publishing.

Pajares, F. (1996). Self-efficacy believes in academic settings. Review of Educational Research, 66 (4), 543-578.

Palečková, J., Tomášek, V., Basl, J., Blažek, R., \& Boudová, S. (2013). Hlavní zjištění z šetření PISA 2012. Praha: ČŠI.

Píšová, M., \& Duschinská, K. (2011). Mentoring v učitelství. Praha: Pedagogická fakulta UK.

Poledňová, I. (2006). Výkonová motivace v prostředí školy - souvislosti se sebepojetím a utvárením sociálních vztahů. Vztahy v dospívání. Brno: Barrister \& Principal.

Rozkovcová, A. (2014). Učitel začátečník v kontextu vnímané sebeúčinnosti a jeho pregraduální př́prava v rovině osobnostního a profesního rozvoje. Příspěvek na XXII. ročníku konference České asociace pedagogického výzkumu, Olomouc.

Starý, K., Dvořák, D., Greger, D., \& Duschinská, K. (2012). Profesní rozvoj učitelů: Podpora učitelů pro zlepšování výsledků žáků. Praha: Karolinum.

Urbánek, T., \& Čermák, I. (1996). Self-efficacy dětí ve školní činnosti. In M. Svoboda (Ed.), Osobnost v dimenzích poruchové a neporuchové činnosti. Sborník př́spěvků z konference $k$ nedožitým 90. narozeninám prof. PhDr. Roberta Konečného, CSc. (s. 101-113). Brno: Masarykova univerzita.

Urbánek, T., \& Čermák, I. (1997). Vliv self-efficacy na agresi a depresi u dětí. Československá psychologie, 41(3), 193-199.

Wiegerová, A., Svatoš, T., Pavelková, I., Mareš, J., Hrabal, V., Ficová, L., \& Gavora, P. (2012). Selfefficacy v edukačních souvislostech. Bratislava: SPN.

\section{Autoři}

Mgr. Vendula Kašparová, Masarykova univerzita, Pedagogická fakulta, Institut výzkumu školního vzdělávání, Poříčí 31, 60300 Brno

Mgr. Eva Potužníková, Masarykova univerzita, Pedagogická fakulta, Institut výzkumu školního vzdělávání, Poříčí 31, 60300 Brno

doc. PhDr. Tomáš Janík, Ph.D., M.Ed., Masarykova univerzita, Pedagogická fakulta, Institut výzkumu školního vzdělávání, Poříčí 31, 60300 Brno, e-mail: tjanik@ped.muni.cz 


\title{
Teachers' self-efficacy in the context of their professional development: Findings and challenges of TALIS 2013
}

\begin{abstract}
The paper introduces and discusses selected results of the Teaching and Learning International Survey 2013 namely the second cycle, which included the Czech Republic. In the first part, reasons for initiation of the survey are introduced and its development is described. The paper briefly mentions the theoretical background with special focus on self-efficacy and job satisfaction. Selected results concerning self-efficacy are presented and discussed in relation to professional development and working conditions at schools. It appears that Czech teachers perceive their self-efficacy as lower than teachers in other countries. Despite this fact they do not take part in professional development focused on the areas where they feel less secure as much as is the international average. The results concerning job satisfaction were slightly more positive, especially in connection with work environment. Compared to the international average, Czech teachers participate more frequently in various forms of collaboration and cooperation at schools. Following the results of the survey, it seems beneficial to make use of the potential of positive school climate to make a closer connection between teachers' evaluation and professional development, and to focus professional development on activities that could increase teachers' self-efficacy.
\end{abstract}

Keywords: international comparative study, teachers' professional development, teachers' job satisfaction, teachers' self-efficacy, TALIS 2013

Kasperová, D. (2014). Výchova prưmyslového člověka a firma Bat’a v meziválečném Zlíně. Liberec: TUL.

Kniha tematizuje otázky reformy vzdělávání výchovy ve Zlíně jako součást širšího společensko-ekonomického konceptu batismu, který není interpretován jako ojedinělý pokus o reformu sociálních a výrobních vztahů, ale jako jeden z realizovaných a velmi úspěšných meziválečných pokusů o realizaci sociálního smíru. Výchovné a vzdělávací snahy v meziválečném Zlíně jsou teoreticky uchopeny jako příklad modernizačních snah tzv. první vlny modernizace a jsou postaveny do protikladu s tzv. druhou modernizací, reflexivní modernizací (Giddens) či modernizací modernizace (Beck). Speciální pozornost je věnována otázkám laboretismu a racionalizace, které byly směrodatnými koncepty meziválečného sociálního, ale i pedagogického života. 